\title{
RADIKALISME KAUM MUDA ISLAM TERDIDIK DI MAKASSAR
}

\section{RADICALISM OF EDUCATED MUSLIM YOUTH IN MAKASSAR}

\author{
Syamsurijal \\ Balai Penelitian dan Pengembangan Agama Makassar \\ Jl.A.P.Pettarani No.72. Makassar \\ Email: bhatijalgol@gmail.com
}

Naskah diterima tanggal 4 Oktober 2017. Naskah direvisi 18 Oktober 2017. Naskah disetujui 30 Oktober 2017.

\begin{abstract}
Abstrak
Radikalisme Islam akhir-akhir ini marak di Indonesia. Persekusi atas nama agama, kekerasan, penyegelan rumah ibadah, bahkan aksi-aksi terorisme kerap mewarnai kehidupan kita dalam berbangsa dan bernegara. Dalam situasi tersebut, anak muda muslim, khususnya dari kalangan terdidik diharapkan dapat menjadi pionir untuk mengatasi radikalisme agama ini. Sayangnya, fakta justru menunjukkan sebaliknya. Kalangan muda terdidik muslim seperti mahasiswa dan kalangan siswa justru terjangkiti virus-virus radikalisme. Di kalangan mereka ini radikalisme justru tumbuh dengan pesat. Tulisan ini menggambarkan sejauh mana paham radikalisme ini berkembang di kalangan kaum muda Islam terdidik dan bagaimana hal tersebut bisa terjadi. Ada dua kategori kaum muda terdidik dalam tulisan ini, yaitu mahasiswa Islam di perguruan Tinggi dan siswa di kalangan SMA. Data dalam tulisan ini didapatkan dari penelitian dengan mixed method. Penelitian ini mengombinasikan penelitian kualitatif dan kuantitatif. Data di dapatkan dari empat sampel perguruan tinggi di Makassar, yaitu UNHAS, UNM, UIN dan UMI. Sementara penelitian siswa sampelnya dari SMA I dan MAN I Makassar.
\end{abstract}

Kata kunci: radikalisme, kaum muda, Islam, terdidik

\begin{abstract}
Islamic radicalism has recently developed in Indonesia. Persecution in the name of religion, violence in the name of religion, the sealing of houses of worship, and acts of terrorism often occur in our lives. In this situation, Muslim youth, especially among the educated, are expected to become pioneers to overcome this radicalism. Unfortunately, the facts suggest otherwise. Young educated Muslims like students and high school students are infected with radicalism. Among them religious radicalism is growing rapidly. This paper describes the extent to which this radicalismism develops among educated Muslim youth and how it can happen. There are two categories of educated youth whom this paper refers to, Islamic students in college and students in high school. The data in this paper were obtained from research with mixed method. This research combines qualitative and quantitative research. Data were obtained from four sample colleges in Makassar; UNHAS, UNM, UIN and UMI. Student research sample were of SMA I and MAN I Makassar.
\end{abstract}

Keywords: radicalism, youth, Islam, educated

\section{PENDAHULUAN}

G hirah keagamaan di kalangan anak muda muslim terdidik saat ini tengah membumbung tinggi. Tidak hanya aktif dalam berbagai kegiatan dan organisasi keagamaan, kalangan muda ini juga aktif dalam berbagai kajian atau halaqah keagamaan tertentu. Kaum muda terdidik ini juga aktif memproduksi pemikiran keislaman mereka dalam bentuk media-media cetak. Beberapa yang lain, yang tidak punya keterampilan menulis yang bagus, menampilkan gagasan dan pemikiran keagamaannya melalui media sosial.
Corak berpikir dan gerakan keagamaan dari para kaum muda yang paling menonjol adalah mereka yang bergabung dalam kelompok-kelompok radikal Islam. Kelompok ini sangat aktif dalam kajian keagamaan, aksi turun ke jalan atas nama Islam, menyebarkan buletin, pamflet dan majalah, dan juga paling sering muncul melontarkan gagasan keislamannya di media sosial.

Pemikiran dan gerakan radikal dari kaum muda terdidik ini, tercermin dari munculnya militansi dan fanatisme agama yang kadang-kala sangat ekstrem. Beberapa penelitian yang dilakukan oleh lembaga-lembaga penelitian di Indonesia 
menunjukkan adanya gejala tersebut, di antaranya terjadi pada kalangan mahasiswa dan pelajar SMA.

Penelitian LaKIP pada rentang waktu Oktober 2010 - Januari 2011 pada 59 sekolah swasta dan 41 sekolah negeri di Jabodetabek menunjukkan; hampir $50 \%$ pelajar setuju dengan kekerasan, $14,2 \%$ setuju aksi terorisme, dan $84,8 \%$ juga setuju penegakan Syariat Islam (Fanani, 2013: 5-10).

Gejala yang sama juga ditunjukkan oleh penelitian Maarif Institute. Dalam penelitian yang berjudul "Pemetaan Problem Radikalisme di Kalangan SMU Negeri di Empat Daerah", menunjukkan kecenderungan menguatnya radikalisme di kalangan siswa (Fanani, 2013: 5). Penelitian Syafii Mufid, yang memetakan kelompok masyarakat yang terlibat dalam aksi terorisme cukup mencengangkan. Dominan mereka berasal dari kalangan muda terdidik. Penelitian itu menyebutkan, dominan mereka yang menjadi teroris masih merupakan pelajar SMA, disusul kalangan mahasiswa (Syafii Mufid, 2011).

Beberapa penelitian memang menunjukkan, angka-angka tertinggi dari gerakan radikalisme ini berada di Pulau Jawa. Penelitian Syafii Mufid menunjukkan hal tersebut, di mana penelitiannya menyebutkan, yang paling banyak terlibat aksi-aksi kekerasan dan terorisme adalah etnis Jawa.

Meski kekerasan dan terorisme tidaklah selalu identik dengan radikalisme, namun sebagian dari mereka yang menjadi bagian gerakan radikal Islam mewujudkan tindakannya lewat kekerasan dan terorisme. Dengan demikian, hasil penelitian Syafii, meski hanya menyebut soal terorisme, sudah bisa menjadi petunjuk radikalisme memang berkembang masif di daerah Jawa. Penelitian lain seperti Wahid Institut maupun Setara Institut mengonfirmasi soal tingginya gerakan radikalisme di daerah Jawa, khususnya Jawa Barat (Laporan Kebebasan beragama WI, 2015).

Daerah luar Jawa sendiri, meski tidak semasif di Jawa, tetap saja cukup signifikan. Makassar adalah salah satunya. Sebagaimana daerah lainnya, di Makassar yang paling banyak terlibat dalam gerakan radikalisme adalah kalangan muda terdidik, khususnya pelajar SMA dan mahasiswa.

Pada kalangan siswa, dalam penelitian tentang "Respons Siswa terhadap Radikalisme", semangat itu terlihat dari beberapa jawaban responden. Meski tidak menjadi mainstream penelitian, muncul jawaban-jawaban yang menginginkan formalisasi syariat. Bahkan, di antara mereka ada yang bersedia melakukan tindakan kekerasan dan bom bunuh diri atas nama Islam. Meski sekali lagi jumlahnya tidak banyak, setidaknya menunjukkan adanya geliat radikalisme di kalangan siswa SMA ini.

Penelitian yang dilakukan Tim Balai Litbang Agama Makassar dengan sasaran penelitian kalangan mahasiswa tahun 2010 menunjukkan gejala serupa. Dalam penelitian itu, 63,5\% mahasiswa setuju bentuk Negara Khilafah dan $17,1 \%$ sangat setuju. Sementara ada 59,3\% yang sepakat perdaisasi/formalisasi Syariat Islam dan $14,8 \%$ sangat setuju. Selanjutnya, ada $47,9 \%$ yang menyatakan tidak bersedia dipimpin oleh yang bukan beragama Islam, dan $18,3 \%$ sangat tidak bersedia. Ini berarti, ada $66,2 \%$ yang tidak setuju (Laporan Tim BLA, 2010).

Belum lagi penelitian tentang "Pergeseran Paham Keagamaan Mahasiswa Islam" yang diadakan Balai Litbang Agama Makassar terhadap empat (4) perguruan tinggi besar di Makassar pada 2015. Hasilnya menunjukkan, pemikiran dan sikap berpikir yang moderat dari kalangan anak muda terdidik ini telah bergeser ke arah radikalisme dengan corak berpikir lebih radikal dan fanatik ekstrem (Laporan Tim BLA, 2015).

Data-data ini menunjukkan, geliat radikalisme ternyata meruak pula di kalangan anak muda terdidik di Makassar. Ini tentu saja mematahkan asumsi, gerakan-gerakan radikalisme selama ini yang muncul hanya lahir dari kalangan awam atau preman yang sadar, seperti selama ini dilekatkan terhadap organisasi kemasyarakatan Forum Pembela Islam (FPI).

\section{Tinjauan Pustaka}

Radikalisme beragama memiliki beberapa karakter. Karakter tersebut menurut E. Marty (1992: 21), antara lain; pertama, Pemaknaan literal monolitik terhadap teks kitab suci; kedua, Gerakan ini selalu terkait fanatisme, eksklusivisme, intoleran, militanisme, dan radikal; ketiga, Gerakan ini senantiasa berupaya membersihkan dan berjuang memurnikan agama dari isme-isme modern; keempat, Kaum ini memonopoli kebenaran atas tafsir agama dan karenanya menolak pluralitas pemaknaan kebenaran agama; dan kelima, Kelompok ini menolak segala paham pluralism. Sebab pluralisme disamping adalah anak kandung modernism, juga paham ini mebuat ruang tafsir terhadap teks agama menjadi terbuka lebar.

Karakter kelompok radikalisme agama semacam ini juga ditemukan dalam kelompokkelompok keagamaan tertentu di Indonesia. 
Hal ini tercermin dalam tulisan yang berjudul Perkembangan Paham Keagamaan Transnasional di Indonesia (Syafii Mufid, 2011). Pada tulisan itu ditunjukkan, paham radikalisme agama muncul pada beberapa kelompok Islam, yang kemudian disebutnya sebagai transnasional Islam. Salah satunya, kelompok yang disebut dengan nama Hizbut Tahrir.

Radikalisme Islam di Indonesia, di samping memiliki ciri sebagaimana diuraikan oleh E. Marty di atas, juga punya keinginan untuk mendirikan negara Islam. Dalam tulisan Ilusi Negara Islam (Abdurrahman Wahid, 2009), menunjukkan bagaimana infiltrasi yang dilakukan kelompokkelompok Islam transnasional di Indonesia seperti kelompok wahabi dan Hizbut Tahrir. Kelompok ini dinyatakan, selain melakukan gerakan dakwah agama, juga memiliki agenda-agenda politik. Agenda politiknya antara lain ingin mengganti bentuk NKRI yang berdasarkan Pancasila dengan bentuk negara lain.

Keberadaan paham radikal ini mengakibat cara-cara beragama sebagian umat Islam di Indonesia mengalami pergeseran. Hal ini disebutkan dalam tulisan Agama dan Pergeseran Representasi: Konflik dan Rekonsiliasi di Indonesia (Alamsyah, 2005). Pergesaran paham keagamaan masyarakat terlihat dari paham keagamaan sebelumnya yang toleran dan ramah menjadi cenderung radikal, ekstrem dan bahkan acap kali melakukan tindakan kekerasan terhadap yang berbeda paham.

Pergeseran paham keagamaan juga muncul di kalangan mahasiswa dan siswa. Hal itu ditunjukan dalam penelitian Radikalisme di SMU di Empat daerah (Padeglang, Cianjur, Yogyakarta dan Solo) yang dilakukan oleh Maarif Institute pada 2011. Riset ini kemudian menjadi laporan utama redaksi Jurnal Maarif Institute (Maarif Institute, 2011). Dengan demikian, gejala radikalisme ini memang sedang mencuat di Indonesia. Paham ini menginfiltrasi segenap segmen masyarakat, terutama pada kalangan mudanya. Hal ini pada akhirnya telah melahirkan corak keberIslaman yang berbeda dari sebelumnya, yaitu Islam yang rahmatan lil alamin menjadi Islam radikal dan puritan.

\section{METODE PENELITIAN}

Penelitian dilakukan dengan menggunakan metode kuantitatif dan kualitatif, atau lazim disebut mixed method. Metode ini dilakukan, karena pertama-tama ingin diketahui dulu perspektif kalangan muda terhadap radikalisme, dan karena itu, perlu dilakukan penelitian kuantitatif. Selanjutnya, perspektif kaum muda muslim ini ingin didalami latar belakangnya, mengapa bisa muncul pandangan keagamaan yang mulai mengarah ke intoleransi bahkan radikalisme? Untuk kepentingan mengetahui itu, penelitian ini dilengkapi penelitian kualitatif.

\section{PEMBAHASAN}

\section{Sejarah Radikalisme Kaum Muda Muslim di Makassar}

Hari-hari terakhir ini kita disuguhkan faktafakta yang cukup mencengangkan mengenai kaum muda muslim di Makassar. Beberapa penelitian menyuguhkan data yang menggembirakan dan di saat yang sama mencemaskan. Menggembirakan, karena data-data tersebut menyebutkan ghirah keberislaman kaum muda itu meningkat cukup tajam. Sebaliknya, mencemaskan karena ghirah keagamaan tersebut bergeser secara pasti ke arah radikalisme agama.

Soal semaraknya ghirah keislaman kaum muda dibuktikan dengan keinginan yang besar untuk berhimpun dalam organisasi kepemudaan berbasis agama. Di sekolah-sekolah menengah pertama dan menengah atas muncul rohaniawan Islam (rohis), yaitu satu organisasi siswa yang berkiprah dalam soal keislaman. Tempat itu menjadi arena untuk berbagai aktivitas keislaman. Di kampus-kampus, bermunculan organisasi berbasis Islam, selain organisasi Islam yang sudah ada sebelumnya. Selain itu, Lembaga Dakwah Kampus (LDK) juga mulai marak kembali. Para kaum muda muslim terdidik ini tidak hanya berhimpun dalam organisasi dan beraktivitas sekadar menyemarakkan syiar Islam, namun juga aktif melakukan diskusi dan kajian. Kajian-kajian yang mereka gelar juga tidak sebatas persoalan umat Islam dalam negeri, namun juga melampaui batas-batas negara. Mereka dengan lancar dan lantang membincangkan persoalan negara-negara muslim lainnya.

Bersamaan dengan itu, data-data atau fakta mencemaskan juga menyembul ke permukaan. Beberapa penelitian menyebutkan, ghirah keagamaan tersebut beriringan dengan radikalisme. Dalam beberapa penelitian yang telah dilakukan Balai Litbang Agama Makassar, menunjukkan betapa ghirah keagamaan tersebut menggeser paham keagamaan mereka dari paham Islam yang inklusif menjadi eksklusif, dari paham moderat menjadi ekstrem dan fanatisme buta. Tak hanya itu, kecenderungan untuk melakukan tindakan 
kekerasan atas nama agama juga mengendap dalam pikiran kaum muda muslim tersebut.

Ghirah Keislaman seharusnya bermakna positif, yaitu semangat untuk menegakkan Islam dalam menjalankan ajaran Islam dengan sungguhsungguh. Namun, ia bisa memicu menjadi masalah, jika makna ghirah ini diarahkan pada kemarahan dan emosi. Hamka, seorang tokoh Muhammadiyah pernah memberi makna ghirah ini sebagai kecemburuan. Dalam batas-batas tertentu, makna semacam ini bisa mendorong perasaan cinta terhadap agama, namun juga bisa mendorong menjadi sumbu-sumbu kekerasan beragama.

Lantas, apakah ghirah keagamaan yang mengarah kepada radikalisme agama ini persoalan baru bagi kaum Islam di Indonesia, khususnya di Makassar? Dalam sejarahnya, radikalisme agama ini bukanlah persoalan baru, termasuk di kalangan muda Islam Makassar. Perkembangannya menjadi masif pasca reformasi, karena selain munculnya kebebasan berserikat dan berkumpul, juga karena semakin mudahnya paham-paham keagamaan dari luar berinfiltrasi masuk ke Indonesia.

Di Indonesia, secara umum radikalisme agama ini beriringan dengan gerakan politik yang diusung oleh beberapa kalangan umat Islam. Pertarungan antara kelompok radikalisme dengan nasionalisme dalam membentuk dasar negara memperlihatkan adanya gejala-gejala radikalisme agama di Indonesia ini. Meski memang pada akhirnya, kelompok Islam yang moderat, yaitu NU dan Muhammadiyah di saat-saat yang sangat menentukan, akhirnya mengambil peran yang signifikan. Ketika terjadi perdebatan tentang Dasar Negara, tokoh-tokoh Islam NU dan Muhammadiyah, menyetujui untuk menghilangkan tujuh kata pada Piagam Jakarta; "Dengan kewajiban menjalankan Syariat Islam Bagi Pemeluknya”.

Setelah peristiwa itu, kelompok-kelompok radikal Islam, bukannya surut, malah muncul dengan memproklamirkan Negara Islam Indonesia atau yang lebih dikenal dengan DII yang dikomandoi oleh Kartosuwiryo (Anhar Gonggong, 2004). Gerakan ini pun disambut di Sulsel oleh Kahar Muzakkar. Kontak pertama antara Kortosuwiryo dengan Kahar Muzakkar terjadi pada 1951. Saat itu, Kortosuwiryo mengirim surat kepada Kahar dan menawarkan untuk membentuk Komandemen TII di Sulawesi dan Kahar yang menjadi pucuk pimpinannya. Tawaran ini di terima Kahar Muzakkar pada 20 Januari 1952 (Van Dick, 1983: 175).
Maka, sejak 1952, gerombolan Kahar Muzakkar pun memaklumatkan bergabung di bawah Gerakan DI/TII Kartosuwiryo. Gerakan DI/TII di bawah kepemimpinan Kahar Muzakkar mulai unjuk-gigi di Sulawesi-Selatan dan sekitarnya. Dalam titi mangsa inilah, fundamentalisme dan radikalisme bersemi di Sulawesi Selatan.

Dalam upaya mendirikan Darul Islam Indonesia, Kahar Muzakkar merekrut kalangan muda untuk turut serta dalam aksinya. Gerakan ini tidak hanya mencita-citakan berdirinya Negara Islam di Indonesia Timur, namun juga menyebarkan paham-paham keagamaan puritan. Hal ini terkait perintah Kortosuwiryo untuk menjadikan rakyat "Bersemangat Islam" dan bersemangat "Negara Islam" (Van Dick, 1983: 175). Terma itu tidak hanya mendorong Kahar untuk melakukan pemberontakan terhadap NKRI, tapi juga menginginkan Kahar menyebar paham keislaman puritan. Kelompok kelompok yang tidak sehaluan dalam pemahaman keagamaan disingkirkan. Ulama-ulama di Sulsel diculik dan dipaksa ikut dalam arus pemahaman keagamaan yang dimiliki oleh Kahar Muzakkar.

Ulama-ulama NU dan masyarakat NU itu berada pada situasi yang suram nan pelik. Tradisi keagamaan NU dilarang. Ziarah kubur, barazanji, perayaan maulid, serta penghormatan pada bendera saat upacara tabu dilakukan.

Sementara itu, masyarakat Sulawesi Selatan yang kebanyakan punya tradisi lokal dengan berbagai pernak-pernik kebudayaannya pun diancam akan dihabisi oleh gerombolan DI/TII pimpinan Kahar Muzakkar ini. Komunitas Tanah Toa Kajang di Bulukumba yang kental dengan tradisinya diserang oleh salah satu sayap Pasukan Kahar yang menjadi momok saat itu. Masyarakat mengenalinya sebagai pasukan "Momok Hitam". Mungkin digelari demikian, karena setiap kedatangannya selalu mengenakan pakaian hitam. Kelompok ini menteror masyarakat. Masyarakat dipaksa untuk tidak menyelenggarakan pesta perkawinan apalagi dengan embel-embel tradisi. Mereka merusak tempat-tempat yang dianggap sakral oleh masyarakat Tanah Toa Kajang. Bahkan menangkapi tokoh-tokoh adatnya. Hal inilah yang memaksa masyarakat Tanah Toa kajang membentuk pasukan sendiri untuk menghadapinya. Kelak, pasukan ini dikenal sebagai "Pasukan Dompea".

Hal yang sama dialami komunitas Bissu. Kelompok transvestites Bugis ini diburu oleh pasukan Kahar. Mereka dipakas kembali menjadi 
lelaki sejati, dan menghentikan kegiatan kebudayaan mereka. Banyak di antara para bissu ini akhirnya menjadi korban dari gerakan radikalisme Islam yang dilancarkan Kahar Muzakkar dan pengikutnya.

Gerkakan DI/TII dan pasukannya ini sebenarnya lebih banyak terjadi di daerah-daerah. Makassar sendiri sebagai ibukota provensi, sebenarnya tidak terlalu terpengaruh dengan gerakan DI/TII. Makassar saat itu masih dikuasai oleh Tentara Republik. Namun pengaruh pemikiran Islam radikal dari Kahar dan gerombolannya menyelusup di kalangan pemuda saat itu.

Sebelum munculnya gerakan DI/TII, di Makassar sudah terlebih dahulu berkembang organisasi Islam yang cukup puritan yaitu Muhammadiyah. Organisasi ini berdiri sekitar tahun 1926, dirintis Mansyur Yamani, seorang pedagang keturunan Arab yang berasal dari Sumenep (Wahab Radjab, 1999: 9).

Sejak 1927, Muhammadiyah telah mendirikan lembaga kepemudaan dan lembaga pendidikan. Di antaranya, Muhammadiyah mendirikan organisasi kepanduan Hizbul Wathan, mendirikan sekolah Holladsche Inlandsche School (HIS) dan Munir School. Guru guru Islam pun didatangkan di antaranya Buya Hamka, Amrullah, dan Zainal Dahlan (Wahab Radjab, 1999). Corak keagamaan yang dikembangkan Muhammadiyah saat itu sebenarnya cukup puritan. Dakwah mereka secara tegas menantang praktik keagamaan yang menurut Muhammadiyah dipenuhi takhayul, bid'ah, dan khurafat, atau yang dikenal dengan istilah TBC.

Muhammadiyah yang didirikan $\mathrm{KH}$ Ahmad Dahlan terinspirasi oleh gerakan pembaharuan Islam yang saat itu berlangsung di Timur Tengah. KH Ahmad Dahlan banyak dipengaruhi tokohtokoh pembaharu Islam semacam Ibn Taiymiyah, Jalaluddin al-Afghan, Muhammad Abduh dan Rasyid Ridha. Sikap-sikap mereka yang antipati terhadap adanya unsur-unsur kebudayaan dalam ajaran Islam menjadikan mereka sebagai tokoh garda terdepan dalam "memurnikan Islam". Mereka menganggap kemunduran Islam disebabkan karena pikiran yang jumud dan sekaligus banyaknya praktik-praktik berbau takhayul, bid'ah, dan khurafat. Praktik sufi dan tasawuf dalam Islam dianggap bagian dari anasiranasir yang mengganggu Islam.

Cara berpikir para tokoh pembaharu tersebut dianggap sebagian kalangan sebagai Islam revivalis atau sahwah al-Islamiyah (Kebangkitan Islam). Ungkapan itu muncul dalam uraian Roxanne
L.Euben, yang menyatakan, kelompok semacam ini bisa disebut sebagai Kebangkitan Islam. Istilah ini menunjukkan gejala kebangkitan Islam yang diiringi oleh militansi yang luar biasa bahkan cenderung ekstrem (Roxanna, 2002: 41). Namun, ada pula yang mengasumsikan, seperti Abu al-Fadhl, gerakan mereka lebih tepat disebut puritanisme. Disebut demikian, karena selain untuk memurnikan agama, mereka juga memiliki sikap absolutism dan tak kenal kompromi pada paham yang diangap tidak murni Islam, khususnya jika ada unsur kebudayaan dan tradisi masyarakat dalam proses beragama (Al-Fadl, 2005: 18). Corak keagamaan semacam inilah yang mewarnai Muhammadiyah dalam memperjuangkan dakwah Islamnya di Indonesia. Corak keagamaan yang demikian pula yang dikembangkan Muhammadiyah di Makassar.

Meski bercorak puritan, gerakan keislaman yang ditempuh Muhammadiyah menghindari terlibat langsung dalam gerakan politik saat itu. Mitsou Nakamura menggambarkan sikap Muhammadiyah sebagai satu kehati-hatian untuk menghindari tekanan pemerintah terhadap kelompok Islam fundamentalis-fanatik (Nakamura, 1983: 123). Dengan hanya menekankan dakwahnya di bidang pendidikan, Muhammadiyah muncul dalam wajah yang tidak garang.

Pengaruh pemahaman Muhammadiyah yang puritan di kalangan anak muda terdidik Makassar mendapat bahan bakar dari gerakan DI/TII. Tentu saja DI/TII tidak sehaluan dengan organisasi ini, namun pemahaman keagamaan yang hampir mirip satu sama lain, telah mendorong kalangan muda yang digodok di lembaga pendidikan Muhammadiyah ini bergerak dari sekadar puritanisme menjadi radikalisme. Pikiran-pikiran radikal-fundamentalis dari Kahar Muzakkar dan anggotanya seakan menjadi stimulus bagi pikiran anak muda terdidik Muhammadiyah.

Inilah yang mendorong munculnya sikapsikap keagamaan radikal dari kalangan muda terdidik di Makassar. Demikianlah, tahuntahun (1950-1965) di mana terjadi peristiwa pemberontakan DI/TII, adalah tahun-tahun paham keagamaan yang radikal-fundamentalis di Makassar mulai mekar. Pada tahun-tahun inilah menjadi cikal-bakal munculnya kelompok-kelompok Islam radikal di Makassar, khususnya di kalangan muda. Pengaruh paham keagamaan Muhammadiyah yang puritan mendapatkan suntikan dari gerakan yang dikembangkan Kahar Muzakkar. Tentu saja pengaruhnya tidak secara langsung, melainkan 
membangkitkan semangat radikalisme yang memang sudah tertanam akarnya pada anak-anak muda Islam di Makassar, khususnya yang ikut dalam lembaga pendidikan Muhammadiyah.

Hal ini ditandai dalam gerakan-gerakan purifikasi Islam selanjutnya, kelompok-kelompok muda terdidik dari Muhammadiyah turut serta di dalamnya. Pemuda Muhammadiyah turut terlibat dalam operasi mappatoba, di mana Bissu yang ada di Pangkep menjadi sasaran penangkapan. Setelah Orde Baru muncul, hampir semua organisasi Islam radikal tiarap. Masa itu kebebasan untuk mengekspresikan pendapat, berserikat dan berkumpul tidak mendapat ruang yang cukup. Meski demikian, kelompok-kelompok radikal pada era ini tetap beraktivitas, meski lebih banyak dalam selubung. Untuk menjaga kelangsungan aktivitas mereka, kelompokini mendirikan Lembaga Dakwah Kampus. Melalui lembaga ini, aktivitas kelompok puritan-radikal tetap berjalan meski dalam selubung kegiatan-kegiatan keagamaan. Masa-masa Orde Baru di Makassar tidak banyak tindakan-tindakan radikal yang dilakukan oleh kelompok-kelompok ini, mereka hanya sibuk melakukan pendidikan dan pengaderan di tingkat LDK-nya masing-masing.

\section{Perkembangan Radikalisme Kaum Muda Muslim Terdidik Pasca Reformasi}

Masa Orde Baru dianggap sebagai masa di mana identitas-identitas primordial tidak dimungkinkan untuk menyembul. Identitas kedaerahan, etnis, dan agama, kesemuanya tak ada yang bisa muncul ke permukaan. Berbagai aturan pada masa Orde Baru dibuat untuk meredam kemungkinan munculnya identitas yang bersifat primordial. Identitas disusun secara integratif.

Pasca reformasi, mana kala legitimasi pemerintahan Orde Baru runtuh dan integrisme nasional yang dibangun mulai ringkih, bangkitlah identitas-identitas primordial yang dibungkam tadi. Identitas primordial muncul seakan-akan mengatasi identitas nasional. Individu-individu (modern) dalam kesatuan masyarakat saat ini secara terusmenerus sedang mengelaborasi identitas partikular dalam bentuk identitas primordial sebagai bangsa, etnis, bahkan agama.

Kejadian ini memang tidak khas Indonesia, Kymlicka (1995) mensinyalir di berbagai belahan dunia telah terjadi pergeseran dari isu nasionalisme sebagai bentuk perjuangan negara-negara yang dijajah oleh negara lain ke arah gugatan nation state yang merupakan kontainer nasionalisme. Gugatan itu muncul dari bawah dengan isu-isu identitas primordial.

Di Indonesia menemukan momentumnya pasca reformasi. Penguatan identitas itu muncul dalam bentuk gerakan politik identitas yang mendasarkan dirinya pada etnis dan agama tertentu. Gerakan identitas etnis muncul dengan menguatnya etnis-etnis yang selama ini merasa dipinggirkan, seperti Dayak, Papua, Aceh, dan seterusnya. Sementara itu, identitas agama muncul dalam bentuk tumbuh suburnya kelompokkelompok keagamaan, khususnya dalam tubuh Islam. Kelompok-kelompok keagamaan baru yang muncul ini, tidak hanya berlatar belakang dalam negeri, tapi banyak di antaranya yang berasal dari luar. Organisasi Islam yang basisnya tidak di Indonesia, namun jauh di luar negeri. Kelompok terakhir ini lazim disebut Islam trans-nasional.

Selain itu, menguatnya identitas agama (Islam) ditandai dengan desakan beberapa kelompok Islam untuk mengubah bentuk atau setidaknya Dasar Negara Indonesia. Hal ini mencuat kembali ketika mulai muncul perdebatan seputar amandemen UUD 1945. Beberapa kelompok yang mengatasnamakan kepentingan Islam seperti FPI, Hizbut Tahrir, KISDI, Forum Komunikasi Ahlussunna Wal Jamaah, Persaudaraan Pekerja Muslim Indonesia (PPMI) dan Majelis Mujahidin melakukan aksi menuntut dikembalikannya Piagam Jakarta (Marzuki, 2007: 1).

Pada saat itu, beberapa kalangan mengagendakan tujuh kata dalam Piagam Jakarta dimasukkan kembali ke dalam UUD 1945. Meski kemudian usulan yang diusung oleh partai-partai Islam ini ditolak oleh mayoritas anggota legislatif, termasuk kalangan Islam di luar parlemen, namun hal ini telah mempengaruhi kebijakan-kebijakan yang muncul di daerah.

Dengan Otonomi Daerah saat itu melalui UU No. 22/1999 tentang Pemerintah Daerah, dan UU No. 25/ 1999 tentang Perimbangan Keuangan antara Pemerintah Pusat dan Pemerintah Daerah, kalangan Islam yang ingin menjadikan Syariat sebagai landasan konstitusi menemukan lahannya. Panggung inilah yang dimanfaatkan oleh kelompok Islam tertentu untuk merumuskan Perda-Perda "Syariat Islam".

Salah satu daerah yang paling getol mendorong issu Perda Syariat Islam adalah Sulawesi Selatan. Di tempat inilah lahir Komite Persiapan Penegakan Syariat Islam (KPPSI) yang bermarkas di Makassar. Pengurus dan anggota KPPSI ini rata-rata berasal 
dari kelompok Islam puritan. Bahkan, ketuanya sendiri adalah putra dari Kahar Muzakkar, yaitu Azis Kahar Muzakkar.

Sebelum KPPSI muncul dengan agenda mendorong perda-perda syariat Islam di tingkat kabupaten, di beberapa tempat muncul kelompokkelompok masyarakat yang mengatasnamakan Syariat Islam dalam menyelesaikan kasus-kasus kriminal di tengah masyarakat. Di Bone ada Forum Bersama, di Bantaeng ada Forum Massa KALBA, demikian halnya di Jeneponto, di Sinjai, Bulukumba, dan Maros.

Kelompok yang kelak dikenal sebagai "massa" ini melakukan tindakan penghakiman terhadap pelaku-pelaku kriminal. Cara-cara penghakiman itu diasumsikan sebagai bagian dari pelaksanaan Syariat Islam. Terlepas bahwa, masyarakat merasa kecewa dengan pelaksanaan hukuman yang dilakukan oleh negara sehingga melakukan tindakan hukum sendiri, namun gerakan "massa" ini menunjukkan mencuatnya kembali radikalisme Islam di Sulawesi Selatan.

Gerakan "massa" ini akhirnya lebur dalam KPPSI, saat organisasi ini mendeklarasikan dirinya pada 15 April 2001, diawali dengan pernyataan bersama yang dikenal dengan Deklarasi Muharram oleh Komite Daerah se-Sulawesi Selatan. Misi KPPSI adalah penegakan syariat Islam di Sulawesi Selatan secara legal formal melalui perjuangan politik konstitusional, demokratis dan tetap dalam bingkai NKRI, guna memperoleh otonomi khusus, sehingga syariat Islam menjadi sumber rujukan dalam kehidupan pribadi, masyarkat, berbangsa dan bernegara (Muawiyyah Ramli, 2007: 131-161).

Komite ini diinisiasi oleh beberapa anak muda yang tergabung dalam Forum Umat Islam. Di antara tokoh muda Islam tersebut, antara lain; Azis Kahar, Aswar Hasan, dan Agus Dwi Karna. Mereka merasa pada waktu itu terbuka ruang untuk menegakkan syariat Islam melalui jalur struktural di Sulsel. Dalam pemikiran para inisiator tersebut, syariat Islam perlu ditegakkan melalui jalur struktural. Penegakan syariat Islam dengan memilih jalur kultural, selama ini belum bisa maksimal menggerakkan masyarakat secara konsisten dan kaffah menjalankan syariat. KPPSI pun marak melangsungkan seminar dan lokakarya untuk mensosialisasikan pentingnya penegakan syariat Islam melalui struktur kekuasaan ini. Di samping itu, kelompok ini intensif mensosialisasikan gagasannya melalui media-media lokal (Muawiyyah, 2007: 131161).
Selain munculnya KPSSI dengan anak-anak muda muslim terdidik yang menjadi pelopornya, di tingkat mahasiswa dan siswa juga mekar organisasiorganisasi yang berbasis keislaman. Sebelumnya, di tingkat mahasiswa hanya dikenal organisasi ekstra kampus semacam Himpunan Mahasiswa Islam (HMI), Pergerakan Mahasiswa Islam Indonesia (PMII), dan juga Ikatan Mahasiswa Muhammadiyah (IMM). Pasca reformasi, organisasi lain juga mulai berkembang. Perkembangan organisasi Islam yang begitu dinamis di kampus selain karena kebebasan berserikat dan berekspresi sudah mendapatkan ruang yang luas, juga karena selama masa orde baru kelompok Islam yang merasa tertekan, kini bisa bergeliat lagi. Setidaknya, demikianlah penjelasan Aswar Hasan salah satu pentolan KPPSI:

Dari sejak Indonesia Merdeka, ideologi pembangunan yang selalu dijiwai oleh komunisme (periode soekarno), kapitalisme (periode soeharto) dan nasionalisme periode (Habibie, Gusdur dan Megawati), semuanya justru tidak membawa bangsa ini menjadi lebih baik. Sementara Islam tidak diberi peluang sedikit pun untuk mengatur bangsa ini, kecuali yang menguntungkan secara materil, yaitu masalah zakat dan haji.

Kelompok sebelumnya yang lebih banyak bergerak secara senyap, kini muncul dengan lebih ekspresif. Kelompok Islam transnasional semacam HTI, Kelompok Salafi, Kelompok Wahabi, serta Syiah mulai bergeliat di kampus. Bahkan, salah satu kelompok Islam radikal yang selama ini dianggap hanya dihuni masyarakat awam, ternyata telah banyak diminati mahasiswa. Organisasi yang dimaksud adalah FPI, dan di tingkat mahasiswa mereka memiliki sayap bernama Front Mahasiswa Islam (FMI). Di Makassar, Front Mahasiswa Islam ini berkembang cukup baik di Kampus UNISMU, setidaknya demikian penjelasan Rahman, salah satu Panglima FPI Makassar.

Dengan demikian, aksi-aksi FPI di Makassar, tidak bisa dikatakan sebagai aksi masyarakat tak terpelajar, atau bahkan dikatakan aksi preman berjubah. Di tengah-tengah mereka, ternyata telah bercokol anak-anak muda terpelajar yang berasal dari mahasiswa.

Lembaga internal kampus semacam LDK yang dulunya tidak intens beraktivitas, kini mulai bergeliat lagi. LDK ini muncul di beberapa kampus dengan nama-nama studi klub keislaman yang beragam. Selain kelompok yang ada sebelumnya 
mulai menunjukkan aktivitasnya, juga muncul kelompok dan organisasi keislaman lainnya, yang masih baru. Salah satu yang baru muncul adalah kelompok salafi yang berhimpun dalam organisasi Mahasiswa Pencinta Mushallah/Mesjid. Inilah yang terjadi di beberapa kampus di Makassar, khususnya kampus-kampus yang ternama seperti UNHAS, UNM, UIN dan UMI.

Di tingkat SMA dan SMP, organisasi keislaman juga muncul dalam bentuk rohis-rohis di sekolah-sekolah. Selain rohis di sekolah-sekolah, organisasi semacam HTI juga melebarkan sayapnya merekrut kalangan pelajar dari bangku SMP dan SMA ini. Kaum muda intelektual yang berhimpun di KPPSI sejak semula memang bercita-cita untuk mendorong formalisasi Islam. Meski demikian, tujuan akhirnya tidak lain juga mencita-citakan berdirinya negara Islam di Indonesia. Aswar Hasan menjelaskan secara gamblang, perjuangan KPPSI adalah kelanjutan dari perjuangan Kahar Muzakkar yang ingin mendirikan negara Islam. Cuma cara yang ditempuhnya yang berbeda. Jika Kahar melalu perjuangan bersenjata di hutan-hutan, kini keinginan itu diperjuangkan melalui cara-cara konstitusional, demikian istilahnya. Cara-cara konstitusional menurut mereka karena keinginan itu dilakukan tidak melalui pemberontakan, tapi melalui panggung legislatif, melalui aturan-aturan yang ada. Semua hal itu mungkin bagi mereka dalam era demokrasi saat ini.

Lantas, bagaimana paham-paham keagamaan yang berkembang di mahasiswa dan siswa-siswa SMU dan SMP setelah mekarnya organisasiorganisasi baru ini? Pada kalangan mahasiswa tampak telah berkembang paham keagamaan yang radikal atau setidaknya sikap puritan dalam beragama. Salah satu kecenderungan mahasiswa Islam di Makassar ternyata telah terpengaruh dengan keinginan anak muda yang bergabung dalam KPPSI. Wacana formalisasi agama tampaknya juga berkembang di kalangan mahasiswa.

Dalam penelitian Balai Litbang Agama Makassar pada 2010 misalnya, mahasiswa cenderung menerima formalisasi Syariat Islam melalu perda. Sebanyak 59,3\% responden menyatakan setuju dan sebanyak $14,8 \%$ menyatakan sangat setuju. Dengan demikian, $74,1 \%$ responden dari kalangan mahasiswa Makassar yang memberikan persetujuan kepada penerapan perda-perda Syariat Islam.

Kecenderungan mahasiswa menyetujui adanya formaliasi agama di tingkat daerah tentu dipengaruhi oleh keberadaan KPPSI dan juga beberapa organisasi di tingkat mahasiswa yang sangat mendukung isu ini, seperti KAMMI yang dianggap sayap PKS di Mahasiswa. PKS sendiri dianggap sebagai partai yang punya kemiripan dengan Ikhwanul Muslimin, di mana mereka tidak akan serta merta menginginkan tegaknya khilafah. Yang paling penting negara bersangkutan secara formal berdasarkan Islam, jika demikian untuk sementara itu telah cukup bagi mereka.

Namun, selain kecenderungan formalisasi, di kalangan mahasiswa juga sudah berkembang keinginan untuk mendirikan khilafah. Hal ini sejalan dengan berkembangnya organisasi HTI di beberapa kampus di Makassar, seperti UNM, UMI dan UNHAS. Data penelitian Balai Litbang Agama Makassar pada 2010 menunjukkan pula hal tersebut. Sebanyak $63,5 \%$ responden menyatakan setuju, dan sebanyak $17,1 \%$ responden yang menyatakan sangat setuju. Artinya, sebanyak $80,6 \%$ mahasiswa menyatakan persetujuan terhadap ide khilafah Islamiyah.

Kalangan mahasiswajugacenderungintoleran, misalnya menolak membantu pembangunan rumah ibadah agama lain. Juga sama sekali tidak berkehendak dipimpin oleh orang berbeda agama. Sebanyak $51,7 \%$ responden menyatakan tidak bersedia dan bahkan ada 17,1\% menyatakan sangat tidak bersedia memberi bantuan. Sementara ada lebih 56 yang menyatakan tidak bersedia dipimpin non muslim.

Sebagian besar mahasiswa yang memberikan respons negatif berasal dari mahasiswa jurusan eksakta. Sedangkan responden yang memberikan respons positif sebagian besar berasal dari jurusan sosial. Hal ini sejalan penelitian Diego Gambetta dan Steffen Hertog, yang menunjukkan, kelompok ekstrem Islam di dunia yang berasal dari dunia kampus didominasi oleh para sarjana atau mahasiswa eksakta, terutama dari teknik. (Diego Gambetta, 2017: 17)

Bagaimana dengan kalangan pelajar SMP dan SMA? Ternyata, setali tiga uang. Radikalisme di kalangan anak sekolah ini tak kalah mencengangkan. Para siswa yang terjaring dalam penelitian Balai Litbang Agama Makassar pada 2016 tentang "Persepsi Siswa terhadap Radikalisme", menunjukkan adanya kecenderungan untuk mengganti dasar negara dengan Alquran dan Sunnah. Sebanyak $45 \%$ cenderung menginginkan hal tersebut, dan menganggap hukum Islam, seperti potong tangan terhadap pencuri wajib dijalankan. Sebanyak 54,4 \% menyatakan hal demikian. 
Sementara pemahaman mereka terhadap jihad adalah suatu perjuangan yang dilakukan kaum muslim dengan jalan peperangan. Makna jihad yang demikian inilah yang dominan ada pada para responden dari kalangan siswa SMA tersebut.

Paham jihad yang demikian adalah asumsi agama yang akhirnya melegalkan perilaku terorisme yang mengatas namakan agama. Inilah yang mengakibatkan adanya siswa yang bersedia melakukan bom bunuh diri atas nama jihad.

Data-data yang menunjukkan adanya kecenderungan terorisme di kalangan pelajar SMP dan SMA di Makassar, sejalan dengan temuan Ahmad Syafii Mufid, yang menunjukkan latar belakang pendidikan para terorisme di Indonesia adalah kalangan anak SMA atau setingkat SMA. Data dalam penelitian itu menunjukkan adanya $63,6 \%$ pelaku terorisme berpendidikan setingkat SMA (Syafii Mufid, 2011: 17).

Menurut Zora A. Subekti, jaringan terorisme memiliki tiga lapisan. Lapisan pertama adalah para idiolog; mereka inilah para pencetus ide-ide dan konsep. Mereka dianggap tokoh agama yang bisa memberi berkat, fatwa dan naehat keagamaan. Lapisan kedua adalah organisatoris, mereka yang berhimpun di lapisan inilah yang menggerakkan jaringan. Mereka menjadi pelobi, negosiator, perekrut, pelatih, pemimpin dalam struktur resmi dan pembuat keputusan di lapangan. Sementara lapisan terakhir adalah pengikut, kelompok terakhir ini kebanyakan kaum muda. Mereka yang menjadi perakit, operator alat, pendukung aksi, penyembunyi informasi dan juga para "pengantin" (pelaku langsung bom bunuh diri) (Zora, 2013). Para Pelajar SMA dan SMP yang menjadi bagian dari lapisan ketiga ini. Mereka kebanyakan menjadi pelaku langsung akibat doktrin yang luar biasa yang telah mencengkau kepala mereka.

Para idiolog dan organisatoris ini sebenarnya mempengaruhi kaum muda tidak hanya dengan melakukan perekrutan secara langsung, lalu melakukan pengaderan. Untuk memengaruhi kalangan muda, dua kelompok lapisan teratas dari teroris ini memanfaatkan media, khususnya mediamedia on line.

Siswa-siswa di Makassar yang orientasi paham keagamaannya seperti tergambar di atas dominan dipengaruhi wacana beberapa kelompok organisasi Islam yang menginginkan bentuk negara ini berubah menjadi negara Islam atau sebagian lainnya menginginkan menjadi khilafah Islamiyah. Isu tentang khilafah Islam ini diserap oleh siswa dari kelompok Hizbut Tahrir. Kelompok yang di Indonesia menyebut dirinya sebagai Hizbut Tahrir Indonesia (HTI) memang menginginkan negara Indonesia menjadi bagian dari khilafah Islamiyah yang mereka idam-idamkan. Bentuk negara kita saat ini, yang bebrbentuk republik lebur dalam khilafah yang menginternasional, demikian kata Syarifuddin Jurdi (Jurdi, 2008: 383: 384).

Bagi penggagas konsep ini, Taqiyyudin Annabhani, sistem khilafah yang memerintah semua daerah muslim adalah salah satu kewajiban agama, sebagaimana wajibnya salat dan puasa. Dasarnya adalah Alquran dan hadist (Taqiyyuddin, 2007).

Doktrin khilafah Islamiyah sebagai kewajiban agama inilah yang banyak mempengaruhi kalangan siswa SMP dan SMA di Makassar sebagaimana terungkap pada data-data di atas. Kelompok HTI ini masuk melalui oragnisasi sekolah seperti OSIS melalui seksi kerohanian yang dikenal dengan rohis. Aktivis-aktivis dari HTI ini menjadi mentor dalam pelatihan yang diadakan rohis tersebut, misalnya Pelatihan Kepemimpinan Dasar. Seorang guru dari salah satu SMP di Makassar secara terangterangan mengatakan, dalam beberapa pelatihan kepemimpinan di sekolahnya dilakukan kelompok HTI ini. Mereka telah menyiapkan tim untuk terlibat dalam berbagai kegiatan pelatihan dan kegiatan kerohanian di sekolah.

Tentu proses, sebagaimana diuraikan di atas tidaklah serta merta. HTI melakukan proses infiltrasi ke SMP dan SMA diawali terlebih dahulu dengan relasi inter-personal. Cara ini adalah pendekatan yang paling halus, karena yang diajak lebih awal untuk berhubungan adalah orang-orang atau keluarga yang ada di sekolah bersangkutan. Jalan akan semakin lempang jika personal yang dekat dengan salah satu aktivis HTI itu kebetulan adalah pengurus OSIS. Melalui dan dengan person tersebutlah, para aktivis HTI ini kemudian bergerak untuk terlibat dalam berbagai acara OSIS, khususnya terkait pelatihan. Jika mungkin HTI melalui rohis ini akan mengambilalih pelatihan tersebut dan memberikan pembinaan ala HTI yang disebut dengan tasykif. Jika sudah melalu pembinaan dasar ini, maka sesungguhnya siswa itu telah menjadi kader HTI dan telah di doktrin konsep khilafah Islamiyah.

Dari uraian di atas terkait dengan mahasiswa dan siswa terlihat, gejala-gejala radikalisme mulai menjangkiti kalangan muda Islam ini. Berapa ciri dan karakter radikalisme Islam mulai muncul pada 
kalangan anak muda ini, setidaknya demikianlah yang dikatakan Martin E. Marty (E. Marty, 1992: 21-35):

Pertama; pemaknaan literal monolitik terhadap teks kitab suci. Bagi kalangan fundamentalis, mencoba memaknai teks kitab suci secara kontekstual ataupun dengan pendekatan lain semacam hermeneutika akan merusak makna transedental dari teks itu. Karena itu teks suci harus dimaknai sesuai dengan arti literalnya. Bukan hanya dimaknai secara harfiah, namun juga tertutup dalam melihat kompleksitas satu teks.

Kedua; gerakan fundamentalisme selalu terkait fanatisme, ekskulsifisme, intoleran, militanisme dan radikal (membolehkan kekerasan). Yang terakhir, perlu mendapat garis bawah. Sebab radikal yang dimaksudkan disini adalah sikap yang keras dan keinginan untuk merubah sesuatu yang dianggap tidak sejalan tanpa kompromi. Tentu saja sikap radikal ini harus dibedakan dengan kritis radikal, sebagaimana ditunjukkan oleh para pemikir kiri Islam atau kalangan teologi pembebasan katolik. Sebab, yang terakhir ini, mereka dianggap radikal karena melakukan revolusi pemikiran yang betulbetul mengakar, namun tidak dengan sikap yang keras agar pemikirannya diterima.

Ketiga; gerakan ini senantiasa berupaya membersihkan dan berjuang memurnikan agama dari isme-isme modern. Isme modern bagi mereka tidak ubahnya kotoran bagi keyakinan, debu-debu keimanan dan penggoda yang memikat namun menjerumuskan. Modernitas yang mengandung liberalisme, humanism dan pluralisme, bagi kalangan ini adalah ilusi yang akan menjebak ummat beragama ke ruang-ruang kegelapan. Karena itu umat beragama harus tegas. Memilih agama artinya menolak segala isme-isme tadi, meski boleh jadi isme tersebut menawarkan madu.

Keempat; kaum ini memonopoli kebenaran atas tafsir agama dan karenanya menolak pluralitas pemaknaan kebenaran agama. Kebenaran tafsir agama adalah kebenaran yang menurut mereka benar. Di luar itu adalah kekeliruan, dzulumaat (kegelapan), kesesatan bahkan kekafiran. Maka tak usahlah heran jika dengan gampang kelompok ini menuduh yang lain jahiliah, sesat bahkan kafir. Persoalannya boleh jadi sepele, mungkin karena berbeda tafsir terhadap satu kata, stigma sesat bisa dilekatkan.

Kelima; puncaknya, kelompok ini menolak segala paham pluralisme. Sebab pluralisme di samping adalah anak kandung modernisme, juga paham ini membuat ruang tafsir terhadap teks agama menjadi terbuka lebar. Pada saat yang sama paham ini juga menghilangkan kemungkinan memonopoli kebenaran tafsir agama.

\section{PENUTUP}

Radikalisme mulai membayangi pemikiran dan perilaku keagamaan kalangan muda muslim terdidik di Makassar. Kalangan muda muslim terdidik yang dimaksudkan adalah para mahasiswa dan siswa. Dalam penelitian ini, meski radikalisme agama belum secara masif menjadi cara berpikir kelompok mahasiswa dan siswa, namun bayangannya telah menyungkupi kaum muda itu.

Dalam penelitian ini, ada beberapa hal yang dapat dikemukakan; Pertama; radikalisme kalangan muda Islam, khususnya kelompok terdidik di Makassar bukanlah hal baru. Sejarah telah mencatatkan beberapa gerakan radikal kaum muda Islam terpelajar, di Sulsel dan di Makassar, di antaranya adalah sikap dan pikiran beberapa di antara mereka yang setuju dengan perjuangan Kahar Muzakkar mendirikan Negara Islam Indonesia. Gerakan DI/TII adalah di antara yang mempengaruhi nalar radikalisme kaum muda Islam terpelajar ini. Radikalisme di kalangan kaum muda Islam terpelajar ini sempat redup pada masa Orde Baru, karena ketatnya aturan rezim saat itu yang membatasi kebebasan berkumpul dan berserikat

Kedua; pasca reformasi, radikalisme kaum muda Islam terpelajar ini kembali mekar. Bibit yang sempat layu pada masa Orde Baru kembali bersemi, karena terbukanya ruang kebebasan dalam demokrasi. Di saat yang sama globalisasi yang memberikan kesempatan paham-paham keagamaan baru berinfiltrasi ke negara kita membuat radikalisme di kalangan muda Islam terdidik ini mekar dengan cepat. Di Makassar kelompok-kelompok Islam baru berkembang pesat. Sebutlah di antaranya, salafi-wahabi, HTI, dan kelompok-kelompok tarbiyah dari Ikhwanul muslimin. Kelompok-kelompok inilah yang melakukan pengaderan, perekrutan sekaligus mendidik kaum muda Islam terpelajar ini, sehingga sikap keagamaan mereka cenderung puritan dan toleran.

Ketiga; beberapa data yang ditemukan, kalangan mahasiswa, siswa dan yang dianggap mewakili kaum muda terpelajar Makassar ini terlihat kecenderungan untuk memahami teks agama secara tekstual dan literalis, menyetujui tindakan kekerasan atas nama agama, cenderung 
menganggap aksi terorisme sebagai bagian dari jihad, dan kurang bisa menerima kelompok yang berbeda, khususnya kelompok minoritas. Ciri-ciri yang ditunjukkan ini sudah mengarah ke beberapa ciri dan karakter kaum radikal-puritan yang selama ini diungkapkan para ahli.

Keempat, selain ada penetrasi kelompok radikal terhadap kaum muda Islam terpelajar melalui diskusi dan berbagai pengaderan, sikap radikal yang ditunjukkan kaum muda ini juga banyak dipengaruhi oleh informasi dari media sosial, situs-situs media on line dan juga dari media massa, khususnya TV.

\section{UCAPAN TERIMA KASIH}

Tulisan ini bisa terbit atas bantuan para responden di lapangan, yaitu kawan-kawan mahasiswa di Makassar, khususnya mahasiswa Unhas, UNM, UMI, serta siswa-siswa di SMA 1 dan MAN 1. Mereka telah meluangkan waktu untuk mengisi kuesioner dan sudi untuk meladeni wawancara. Demikian juga terima kasih pada rekan peneliti, Irfan Syuhudi dan Suaib Pranowo, yang juga terlibat dalam penelitian ini. Sebagian hasil penelitian mereka berdua melengkapi data-data dalam tulisan ini.

\section{DAFTAR PUSTAKA}

A. Sukabdi, Zora. 2013. "Kaum Muda dan Radikalisme. dalam Jurnal Maarif.Vol.8 No.1-Juli.

Aboe el-Fadl, Khaled. 2005. The great Theft, wrestling Islam from the Extremist. San Fransisco: Harper san fransisco. Annabhani, Taqiyuddin. 2007. Daulah Islam. Jakarta: HTI Press.

Azca, Muhammad Najib. 2013. "Yang Muda, Yang Radikal; Refleksi Sosiologis Terhadap Fenomena Radikalisme Kaum Muda Muslim Indonesia Pasca Orde Baru" dalam Jurnal Maarif. Vol.8, No 1-Juli.

Dick, C. Van. 1983. Darul Islam sebuah Pemborontakan (terj) Rebellion Under The Banner of Islam. Jakarta: Grafiti Pres.

E. Marty, Martin, "What Fundamentalism? Theological Prespective dalam Hans Kung dan Jurgen Moltmann" (ed). 1992. Fundamentalism at Ecumenical Challenge. London: SCM Press.
Fanani, Ahmad Fuad. 2013. "Fenomena Radikalisme di Kalangan Kaum Muda" dalam Jurnal Maarif, Vol.8,No.1-Juli.

Gambetta, Diego dan Steffen Hertog. 2017. (Terjemahan Heru). Para Perancang Jihad. Yogyakarta: Gading Publishing.

Gonggong, Anhar, 2004, Abdul Kahar Muzakkar dari Patriot Hingga Pemborontak. Jakarta: Ombak.

Jurdi, Syarifuddin. 2008. Pemikiran Politik Islam Indonesia: Pertautan Negara, Khilafah, Masyarakat Madani dan Demokrasi. Yogyakarta: Pustaka Pelajar.

Kymlica, Will. 2002. (Terjemahan Edlina Hafmini), Kewargaan Multikultural; Teori Liberal Mengenai Hak-hak Minoritas. Jakarta: LP3S.

L. Euben, Roxanna. 2002. Musuh dalam Cermin, Fundamnetalisme Islam dan Batas Rasionalisme Modern. Jakarta: Serambi.

Laporan Kebebasan Beragama Wahid Institute. 2015.

Tim Peneliti Balai Litbang Agama Makassar. 2016. Respon Siswa terhadap Radikalisme. Makassar: Balai Litbang Agama Makassar.

M.Ja’far, Alamsyah (ed). 2009. Agama dan Pergeseran Representasi: Konflik dan Rekonsiliasi di Indonesia. Jakarta: Wahid Institute.

Nakamura, Mitsou. 1983. Terjemahan Yusron Asrofie, Bulan Sabit Muncul dari Balik Pohon Beringin. Yogyakarta: Gadjah Madah University Press.

Pranowo, Suaib dan Tim Peneliti Balai Litbang Agama Makassar. 2016. Respon Siswa Makassar terhadap Radikalisme. Makassar: Balai Litbang Agama Makassar.

Radjab, H.A. Wahab. 1999. Lintasan Perkembangan dan Sumbangan Muhammadiyah di Sulsel. Jakarta: IPPSDM-WIN.

Ramli, Muawiyah (ed). 2007. Demi Ayat Tuhan; Upaya KPPSI Menegakkan Syariat Islam. Jakarta: OPSI.

Syamsurijal. 2014. Pergeseran Paham Keagamaan Mahasiswa Islam di Makassar. Makassar: Balai Litbang Agama Makassar.

Syafi'i Mufid, Ahmad (ed). 2011, Perkembangan Paham Keagamaan Transnasional di Indonesia. Jakarta: Badan Litbang dan Diklat Jakarta. 2011. Exekutive summary of Research on Motivation and Root Causes of Terrorism. Jakarta: Penerbit Indonesia Institute for society Empowerment.

Wahid, Abdurrahman. 2009. Ilusi Negara Islam. Jakarta: GBTI-WI-Maarif Institute. 